\section{Case Reports in Neurology}

Case Rep Neurol 2020;12:260-265

DOI: 10.1159/000509505

Published online: August 4, 2020
(C) 2020 The Author(s)

Published by S. Karger AG, Basel www.karger.com/crn

This article is licensed under the Creative Commons Attribution-NonCommercial 4.0 International License (CC BY-NC) (http://www.karger.com/Services/OpenAccessLicense). Usage and distribution for commercial purposes requires written permission.

\title{
A Case of Coronavirus Disease 2019 Presenting with Seizures Secondary to Cerebral Venous Sinus Thrombosis
}

\author{
Suhail Hussain ${ }^{a}$ Surjith Vattoth ${ }^{c}$ Khawaja Hassan Haroon ${ }^{a}$ \\ Ahmad Muhammad ${ }^{a, b}$ \\ aNeuroscience Institute, Hamad Medical Corporation, Doha, Qatar; \\ bWeill Cornell Medicine-Qatar, Doha, Qatar; ' University of Arkansas for \\ Medical Sciences, Little Rock, AR, USA
}

\section{Keywords}

Coronavirus disease 2019 - Cerebral venous sinus thrombosis · Seizures

\section{Abstract}

Coronavirus disease 2019 (COVID-19) is an infectious disease caused by severe acute respiratory syndrome coronavirus 2. COVID-19-associated thrombotic events are recognized. A wide variety of neurological presentations have been recently documented. We report the first case of COVID-19 presenting with generalized seizure secondary to cerebral venous sinus thrombosis.

\section{Introduction}

Coronavirus disease 2019 (COVID-19) is an infectious disease caused by severe acute respiratory syndrome coronavirus 2. Its was first reported in Wuhan, China in December 2019. On March 12, 2020 the World Health Organization (WHO) declared COVID-19 a pandemic. According to the WHO situation report of May 16, 2020 there are over 4 million confirmed COVID-19 cases and over 300,000 deaths in 216 countries [1].

The typical presentation of COVID-19 can range from mild to severe respiratory illness [2]. However, recently a wide variety of neurological presentations including seizures have 


\section{Case Reports in Neurology}

Case Rep Neurol 2020;12:260-265

DOI: 10.1159/000509505

(c) 2020 The Author(s). Published by S. Karger AG, Basel www.karger.com/crn

Hussain et al:: COVID-19 Presenting with Seizures Secondary to Cerebral Venous Sinus Thrombosis

been reported [3]. Several recent studies suggest hypercoagulable state in patient presenting with COVID-19 [4]. We report the first case of COVID-19 presenting with generalized seizure secondary to cerebral venous sinus thrombosis (CVST).

\section{Case Presentation}

A 30-year-old man, previously fit and well, was brought to the emergency department with four episodes of witnessed generalized tonic clinical seizures. He had been well prior to the event, with no neurological or respiratory symptoms, and there was no history of similar episodes in the past.

On examination the patient was conscious and oriented, temperature was $36.6^{\circ} \mathrm{C}$, blood pressure was $139 / 81 \mathrm{~mm} \mathrm{Hg}$, respiratory rate was 18 per minute, and oxygen saturation was $99 \%$ on room air. He had no neurological focal deficit. Laboratory results showed lymphocytopenia $0.61 \times 10^{9} / \mathrm{L}$ (normal 1.0-4.5 $\times 10^{9} / \mathrm{L}$ ), raised prothrombin time $15.1 \mathrm{~s}$ (normal 9$12 \mathrm{~s}$ ), raised D-dimer $0.75 \mathrm{mg} / \mathrm{L} \mathrm{FEU} \mathrm{(normal}<0.45 \mathrm{mg} / \mathrm{L} \mathrm{FEU}$ ) and slightly raised AST $44 \mathrm{U} / \mathrm{L}$ (normal 0-40 U/L). The rest of liver function test, renal profile, and C-reactive protein were within normal limits. Ferritin was $91.0 \mu \mathrm{g} / \mathrm{L}$ (normal 48-420 $\mu \mathrm{g} / \mathrm{L}$ ). Serology for hepatitis B surface antigen and hepatitis $\mathrm{C}$ antibody was negative. HIV test was also negative. Protein $\mathrm{C}$ and $\mathrm{S}$ activity, lupus anticoagulants, and anticardiolipin antibodies were all negative. A nasopharyngeal COVID-19 swab taken as per hospital screening protocol was positive. Chest X-ray was normal, with no evidence of ground glass opacities or consolidation.

A CT scan of the head showed a small hypodense lesion in the right temporal lobe anteriorly with mild surrounding edema and mass effect. Tiny foci of hyperdense hemorrhage were seen within the lesion and in the adjacent Sylvian fissure (Fig. 1). MRI showed that the lesion was a hematoma with susceptibility weighted imaging showing blooming hypointense blood products in the lesion and subarachnoid hemorrhage in the Sylvian fissure (Fig. 2). Postcontrast thin 3D T1 MPRAGE images showed nonocclusive filling defects suggestive of clots within the right sphenoparietal venous sinus at the anterior temporal pole (Fig. 3). A postcontrast MR venogram of the head showed nonocclusive venous thrombosis of the torcula, left transverse sinus, and sigmoid sinus, extending to occlude the proximal part of the left internal jugular vein (Fig. 4).

Seizures were controlled with levetiracetam $500 \mathrm{mg}$ twice daily. Following the MRI results, the patient was commenced on subcutaneous low-molecular-weight heparin $1.5 \mathrm{mg} / \mathrm{kg}$ body weight for the first $48 \mathrm{~h}$ and subsequently changed to rivaroxaban $15 \mathrm{mg}$ twice daily for the first 3 weeks, then $20 \mathrm{mg}$ daily for a minimum of 3 months. He did not require any treatment for COVID-19 as he remained asymptomatic. He remained stable through the course of admission and was discharged to a quarantine center.

\section{Conclusion}

COVID-19 is an ongoing global health threat. It is apparent that some patients with COVID19 present with only neurological symptoms as opposed to the typical triad of fever, cough, or dyspnea. Several recent studies suggest hypercoagulable state in patients presenting with COVID-19, increasing the risk of developing arterial and venous thrombosis [4].

The incidence of CVST has been reported as being between 2 and 5 million per year [5]. Unlike arterial stroke that is more prevalent in the elderly, CVST typically affects young adults, 


\section{Case Reports in Neurology}

\begin{tabular}{l|l}
\hline Case Rep Neurol 2020;12:260-265 \\
\hline DOI: 10.1159/000509505 & $\begin{array}{l}\text { @ 2020 The Author(s). Published by S. Karger AG, Basel } \\
\text { www.karger.com/crn }\end{array}$ \\
\hline
\end{tabular}

Hussain et al.: COVID-19 Presenting with Seizures Secondary to Cerebral Venous Sinus Thrombosis

with a mean age of 35 years, and is more common in women than in men (3:1) because of sexspecific risk factors [6]. Seizures are the presenting feature of CVST in $12-32 \%$ of patients, while up to $44 \%$ of patients may have seizures in the early stage of the disease $[7,8]$.

There is emerging evidence of a higher number of thrombotic complications in COVID-19 patients. Our patient did not have any inherited or acquired risk factors for CVST. Presence of lymphocytopenia and high D-dimer in our patient could demonstrate hypercoagulable state as observed by Cui et al. [4] in their study looking at the prevalence of venous thromboembolism in COVID-19 patients. This case highlights the importance of considering COVID-19 a possible risk factor for CVST. Physicians also need to be aware that COVID-19 could present with neurological manifestation like seizures, even in absence of typical symptoms.

\section{Statement of Ethics}

This article was conducted ethically in accordance with the World Medical Association Declaration of Helsinki. The subject in this paper gave written informed consent for publication of his case including publication of images.

\section{Conflict of Interest Statement}

The authors have no conflicts of interest to disclose.

\section{Funding Sources}

There was no funding.

\section{Author Contributions}

S. Hussain and S. Vattoth: writing and editing. K.H. Haroon and A. Muhammad: review and editing.

\section{References}

1 World Health Organization. Coronavirus disease (COVID 19). Situation report - 117. 2020. Available from: www.who.int/docs/default-source/coronaviruse/situation-reports/20200516-covid-19-sitrep-117.pdf? sfvrsn=8f562cc_2.

2 Guan WJ, Ni ZY, Hu Y, Liang WH, Ou CQ, He JX, et al.; China Medical Treatment Expert Group for Covid-19. Clinical characteristics of coronavirus disease 2019 in China. N Engl J Med. 2020 Apr;382(18):1708-20.

3 Moriguchi T, Harii N, Goto J, Harada D, Sugawara H, Takamino J, et al. A first case of meningitis/encephalitis associated with SARS-Coronavirus-2. Int J Infect Dis. 2020 May;94:55-8.

4 Cui S, Chen S, Li X, Liu S, Wang F. Prevalence of venous thromboembolism in patients with severe novel coronavirus pneumonia. J Thromb Haemost. 2020 Jun;18(6):1421-4.

5 Bousser MG, Ferro JM. Cerebral venous thrombosis: an update. Lancet Neurol. 2007 Feb;6(2):162-70.

6 Maali L, Khan S, Qeadan F, Ismail M, Ramaswamy D, Hedna VS. Cerebral venous thrombosis: continental disparities. Neurol Sci. 2017 Nov;38(11):1963-8. 


\section{Case Reports in Neurology}

\begin{tabular}{l|l}
\hline Case Rep Neurol 2020;12:260-265 \\
\hline DOI: 10.1159/000509505 & $\begin{array}{l}\text { @ 2020 The Author(s). Published by S. Karger AG, Basel } \\
\text { www.karger.com/crn }\end{array}$ \\
\hline
\end{tabular}

Hussain et al.: COVID-19 Presenting with Seizures Secondary to Cerebral Venous Sinus Thrombosis

7 Ferro JM, Correia M, Rosas MJ, Pinto AN, Neves G; Cerebral Venous Thrombosis Portuguese Collaborative Study Group [Venoport]. Seizures in cerebral vein and dural sinus thrombosis. Cerebrovasc Dis. 2003; 15(1-2):78-83.

8 Masuhr F, Busch M, Amberger N, Ortwein H, Weih M, Neumann K, et al. Risk and predictors of early epileptic seizures in acute cerebral venous and sinus thrombosis. Eur J Neurol. 2006 Aug;13(8):852-6.

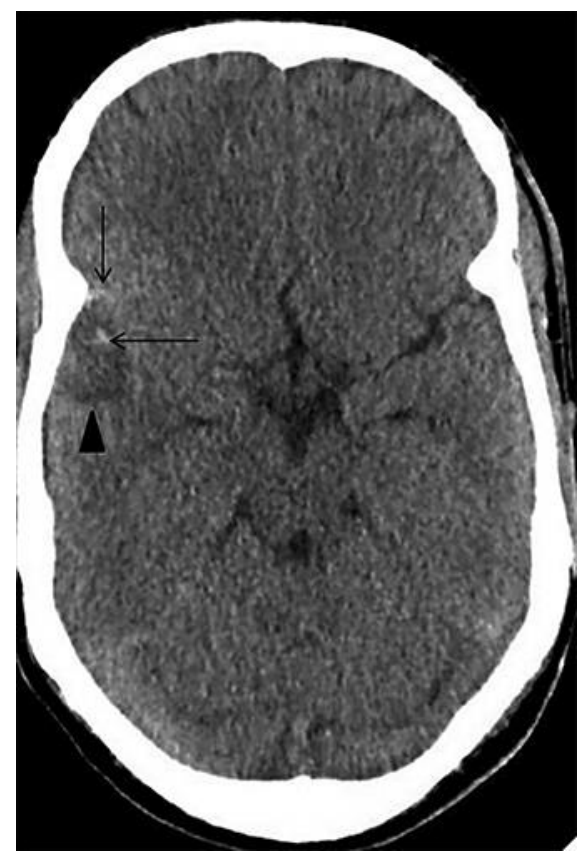

Fig. 1. A CT scan of the head showed a small hypodense lesion in the right temporal lobe anteriorly (arrowhead) with mild surrounding edema and mass effect. Tiny foci of hyperdense hemorrhage were seen within the lesion (horizontal arrow) and in the adjacent Sylvian fissure (vertical arrow). 


\section{Case Reports in Neurology}

\begin{tabular}{l|l}
\hline Case Rep Neurol 2020;12:260-265 \\
\hline DOI: 10.1159/000509505 & $\begin{array}{l}\text { @ 2020 The Author(s). Published by S. Karger AG, Basel } \\
\text { www.karger.com/crn }\end{array}$ \\
\hline
\end{tabular}

Hussain et al.: COVID-19 Presenting with Seizures Secondary to Cerebral Venous Sinus Thrombosis

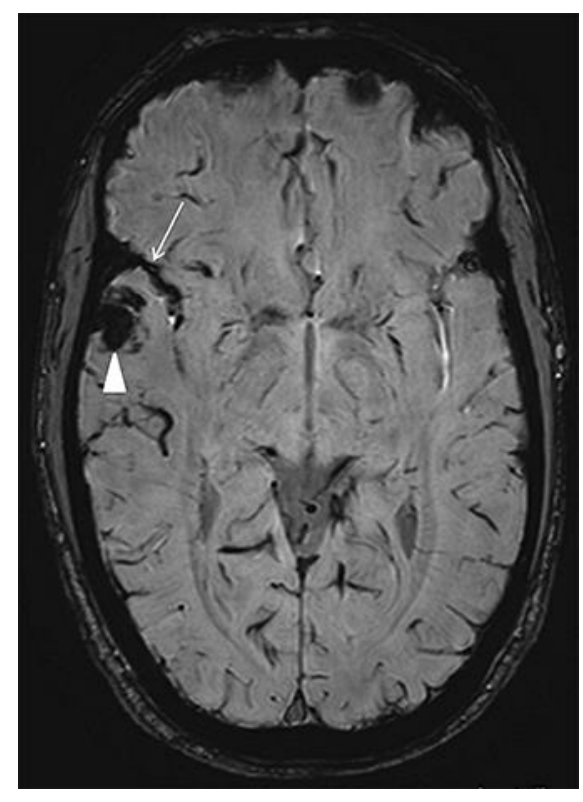

Fig. 2. MRI of the head showed that the lesion was a hematoma, with susceptibility weighted imaging showing blooming hypointense blood products in the lesion (arrowhead) and subarachnoid hemorrhage in the adjacent Sylvian fissure (arrow).

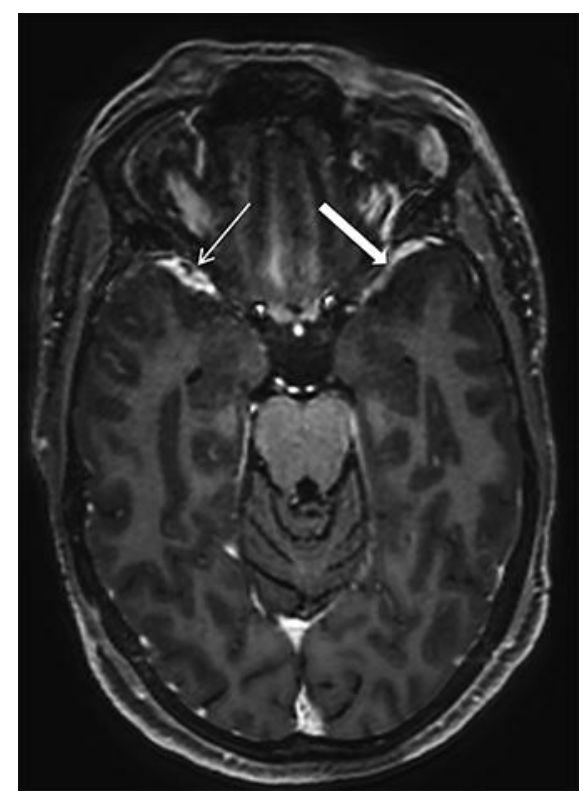

Fig. 3. Postcontrast thin 3D T1 MPRAGE image showed nonocclusive filling defects suggestive of clots within the right sphenoparietal venous sinus at the anterior temporal pole (thin arrow). Note the normal contrast-filled left sphenoparietal sinus for comparison (thick arrow). 
Case Reports in Neurology
Case Rep Neurol 2020;12:260-265

DOI: 10.1159/000509505 (c) 2020 The Author(s)
www.karger.com/crn

Hussain et al.: COVID-19 Presenting with Seizures Secondary to Cerebral Venous Sinus Thrombosis

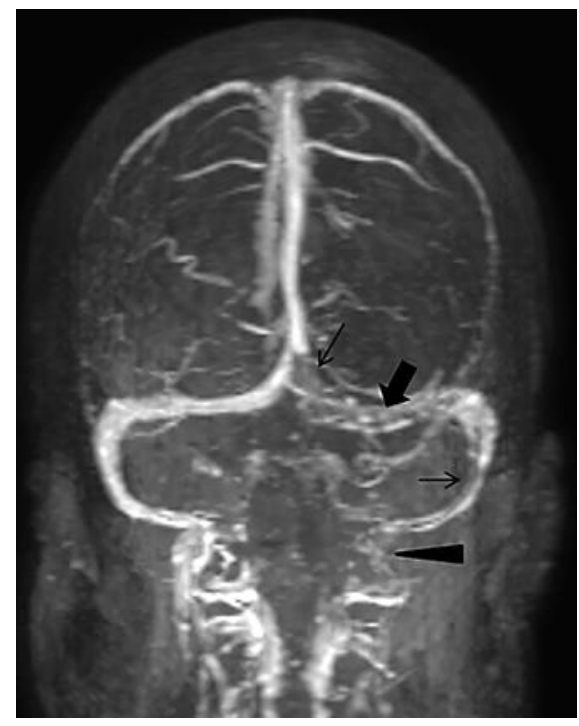

Fig. 4. A postcontrast MR venogram of the head showed nonocclusive venous thrombosis of the torcula (vertical thin arrow), left transverse sinus (thick arrow), and sigmoid sinus (horizontal thin arrow), extending to occlude the proximal part of the left internal jugular vein (arrowhead). 